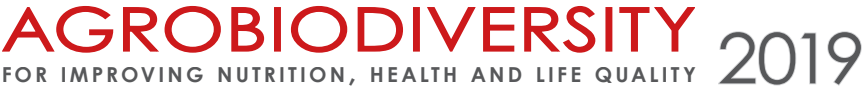

(3)

\section{REACTIONS OF POLLEN OF PLANTS FROM GENUS LYSIMACHIA L. ON DIFERRENT ENVIROMENTAL CONDITIONS}

\author{
Matyashuk Raisa*, Mazura Marina, Yurchuk Mikola
}

Institute for Evolutionary Ecology of NAS of Ukraine, Kyiv, Ukraine

Received: 25. 7. $2019 \quad$ Revised: 18.11.2019 Published: 28. 11. 2019

A cytological study of pollen of different species of the genus Lysimachia L. has been carried out. This is part of the comprehensive study of biological, anatomical, cytological, biochemical and molecular genetic features of the common species in Ukraine of this genus. The genetic collection of the genus Lysimachia has been begun to create on the territory of Feofania Park in Kyiv which is the government designated park. The general appearance and sculpture of pollen grains and the sensitivity of pollen of some species of the genus Lysimachia to different conditions of plant cultivation were studied. The pollen morphology and structure of his shell in of L. nummularia L., L. punctata L. and L. vulgaris L. studied using the scanning electron microscope. The obtained results made it possible to confirm that the shape of pollen grains, the structure of its shell are genetically determined and bear the specific features of the taxon. Growth and development of plants of Lysimachia in different conditions of the environment affect the biometric indices of pollen and its fertility. The sensitivity of pollen to exogenous conditions is elevated during the flowering of plants, compared to the phase of budding. There was a tendency towards a decrease in the diameter of pollen grains with the flower opening of the L. punctata and L. vulgaris in the cultivation of plants in conditions with increased exposure to anthropogenic factors. A high level of pollen fertility for plants of L. nummularia has been established.

Keywords: Lysimachia L., pollen, sensitivity

\section{Вступ}

Процеси формування і розвитку пилку більшості рослин є дуже чутливими до впливу зовнішніх факторів різної етіології, які істотно впливають на поведінку пилкових зерен при проростанні (Bessonova, 1992; Dzyuba, 1999; Glazunova, 2001). Ці фактори значно, а іноді й невпізнаванно, змінюють характер росту пилкових трубок і процес проростання (Golubinskiy, 1974; Petrovich, 1976; Frenkel and Gadun 1982). Ще в минулому столітті паліноіндикація якості оточуючого середовища визнана надійною ланкою в ланцюгу екологічного моніторингу, оскільки реакція чоловічої генеративної сфери рослин (зокрема - пилку) і тварин загалом адекватні (Bessonova, 1992; Dzyuba, 1999;

\footnotetext{
*Corresponding author: Raisa Matyashuk, Institute for Evolutionary Ecology of NAS of Ukraine, Lebedeva 37, 03143 Kyiv, Ukraine $\triangle$ raisakiev2015@gmail.com
} 
Dzyuba et al., 2001). Основою паліноіндикаційного методу є аналіз і облік морфологічних та функціональних характеристик пилку (Dzyuba, 2006, 2014). Паліноіндикація із використанням лісових деревостанів і трав'янистих рослин належить до сучасних методів фітоіндикації стану не лише природних і квазіприродних, але й селітебних ландшафтних комплексів. Пилок використовують як складову інтегрального контролю при визначенні екостанів промислово-господарського, урбанізованого та рекреаційного природокористування (Pogosyan et al., 1991; Bessonova et al., 1994; Gorovaya et al., 2003; Kavelenova, 2003; Bessonova et al., 2013; Grytzay and Tryphonov, 2015). На основі якісного і кількісного аналізу мінливості життєвих показників пилку вищих рослин в Україні здійснюється індикація якості навколишнього природного середовища (Наказ М03 України № 116 від 13. 03. 2007 р.).

Рід Lysimachia містить приблизно 140-200 видів з поширенням по всьому світу і за результатами сучасних досліджень досить активно доповнюється новими видами (Loc and Hu, 2011; Zhang et al., 2012; Zhou et al., 2015; Wang et al., 2016). В Україні наведені 5 видів цього роду (Lysimachia nummularia L. (вербозілля лучне або монетне), L. vulgaris L. (в. звичайне), L. nemorum L. (в. гайове), L. punctata L. (в. крапчасте), L. verticillaris L. (в. кільчасте) (Didukh et al., 2010). 3 них чотири (за винятком L. verticillaris) зростають на території парку-пам'ятки садово-паркового мистецтва загальнодержавного значення «Феофанія» (далі-ППСПМ «Феофанія»). Доситьчасто L.nummularia, L. punctata i L. vulgaris трапляються в природних і напівприродних локалітетах та культурфітоценозах Києва. Цитологічне вивчення пилку різних видів роду Lysimachia $€$ частиною комплексного вивчення біологічних, анатомічних, цитологічних і біохімічних особливостей поширених в Україні представників цього роду.

Це дослідження передбачає визначення чутливості пилку вербозілля до різних умов вирощування, враховуючи їх цінність для збагачення різноманіття, зокрема, декоративних рослин та раціонального використання природних ресурсів.

\section{Матеріали та методи}

\section{Об'єкти дослідження}

Досліджувався пилок видів Lysimachia nummularia, L. punctata, L. nemorum i L. vulgaris, відібраний у фазу бутонізації та цвітіння рослин з різних за антропогенним навантаженням місцезростань в м. Києві, населених пунктів Київської і Полтавської областей. У зазначених міських насадженнях рослини L. nummularia були відібрані з таких територій: ділянка 1 - ППСПМ 'Феофанія' (синантропна ділянка, паркова частина); ділянка 2 - ППСПМ ‘Феофанія' (напівприродна (порушена) лучна ділянка); ділянка 3 - ППСПМ ‘Феофанія’ (лісове угруповання); ділянка 4 - с. Новосілки Київської області (синантропна ділянка); ділянка 5 - парк 'Перемога' м. Київ (синантропна ділянка). Рослини L. punctata були відібрані з об'єктів декоративного озеленення (ділянка 1 - ППСПМ 'Феофанія'; ділянка 2 - вул. академіка Заболотного, м. Київ; ділянка 3 - смт. Гребінка Полтавської області). Пилок L. vulgaris відбирали як в напівприродних локалітетах та малопорушених умовах (ділянка 1 - ППСПМ ‘Феофанія'; ділянка 2 - острів 
Муромець, м. Київ), так і з об’єктів озеленення територій загального користування (ділянка 3 - Оболонська набережна, м. Київ; ділянка 4 - клумба в центральній частині м. Буча Київської обл.).

\section{Морфометричні характеристики}

Вивчалась загальна будова пилкових зерен досліджуваних видів. Сухі пилкові зерна покривали дрібнозернистим золотом за допомогою JEOL Smart Coater та вивчали за допомогою скануючого електронного мікроскопа JEOL JCM-6000 (JEOL Ltd., Toкіо, Японія) з використанням програмного забезпечення Semafore (JEOL, Sollentuna, Швеція). Для дослідження брали свіжозібраний матеріал у фазу цвітіння рослин цього роду зі створеної колекції на території ППСПМ 'Феофанія' Опис пилкових зерен - за прийнятою термінологією (Kupriyanova and Aleshina, 1972, 1978; Tokarev, 2002; Tsymbalyuk and Mosyakin, 2013; Punt et al., 1994). Вимірювання морфометричних параметрів проводили на 30 пилкових зернах кожного зразка з використанням програми AxioVision Rel. 4.8.2.0. Довжину пилкового зерна визначали за довжиною полярної осі (пряма лінія, що з'єднує проксимальний і дистальний полюс), а ширину за розміром екваторіальної осі (перпендикулярна до полярної осі та розташована в екваторіальній площині). Розміри пилкових зерен подані в мікрометрах (мкм).

\section{Визначення фертильності пилку}

Фертильність пилку досліджуваних видів визначали на препаратах, фарбованих за методом йодної реакції (Pausheva, 1988). Для кожного виду досліджували по 100 пилкових зерен на 4 препаратах у фазу бутонізації та цвітіння. В роботі використане наступне наукове обладнання Інституту: стереомікроскоп Leica M205C з комплектуючими; мікроскоп прямий бінокулярний Nikon Eclipse E100; фотоапарат Nikon Coolpix L830. Обробка даних здійснювалась за допомогою ліцензійних програм (Helicon Focus PRO, QuickPHOTO MICRO, Davis WeatherLink) з використанням комп'ютерів на базі Intel Core-i7/DDR 3 2Gb/HDD 500 Gb/DVD-RW.

\section{Статистичний аналіз}

Були визначені основні характеристики згідно методів описової статистики: середнє арифметичне $(M)$, похибка середнього значення $(m), G$ - дисперсія; $V$ - коефіцієнт варіації, \%.

\section{Результати та їх обговорення}

3 використанням скануючої електронної мікрографії визначені типові структури, форми та розміри пилкових зерен для кожного генотипу досліджених видів роду Lysimachia. За зробленим раніше описом (Kupriyanova and Aleshina, 1978; Kurmanov and Ishbirdin, 2012) пилкові зерна L. nummularia - 3-борозно-орові, кулясті, злегка сплюснуті по екватору; в обрисах з полюса слабо 3-лопатеві, з екватора широкоеліптичні, майже округлі; полярна вісь - 27,6-28,8 мкм, екваторіальний діаметр 22,8-25,2 мкм. Борозни широкі, довгі, з рівними краями і притупленими кінцями. Ори екваторіально витягнуті, еліптичні, 2,4-3,0 мкм завдовжки і 1,2-1,8 мкм в ширину. 
Скульптура сітчаста, рівноямчаста, комірки сітки кутасті або округлі, товстостінні, діаметр комірок зменшується в напрямку до борозенок; покрив тонкий, переривчастий, потовщується над групами стовпчиків. Сучасні дослідження морфології пилку і структури оболонки 20 видів Lysimachia з 12 районів Китаю доповнили окремі описи: пилкові зерна сфероїдальні, субсфероїдальні, продовгувато сфероїдальні, продовгуваті. Відношення полярного діаметра до екваторіального 0,97-1,65. Розмір дрібний до середнього 10-28 × 8,5-26,6 мкм. Товщина екзини 0,8-1,5 мкм. Орнаментація горбкувато-дрібноямчаста. Визначені 4 типи пилку на основі розміру, форми, структури, орнаментації секзини: тип Capillipes (підрід Idiophyton), тип Heterogenea (підрід Palladia), тип Hutsunae і тип Christinae (підрід Lysimachia). Створено ключ і еволюційний розвиток чотирьох типів. Найпримітивніший тип Capillipes вирізняється дрібними пилковими зернами 3 горбкувато-дрібноямчастою без колумел структурою, тип Christinae - найбільш спеціалізований з добре розвинутою колумелятною і сітчастою орнаментацією (Shao and Zhang, 2005).

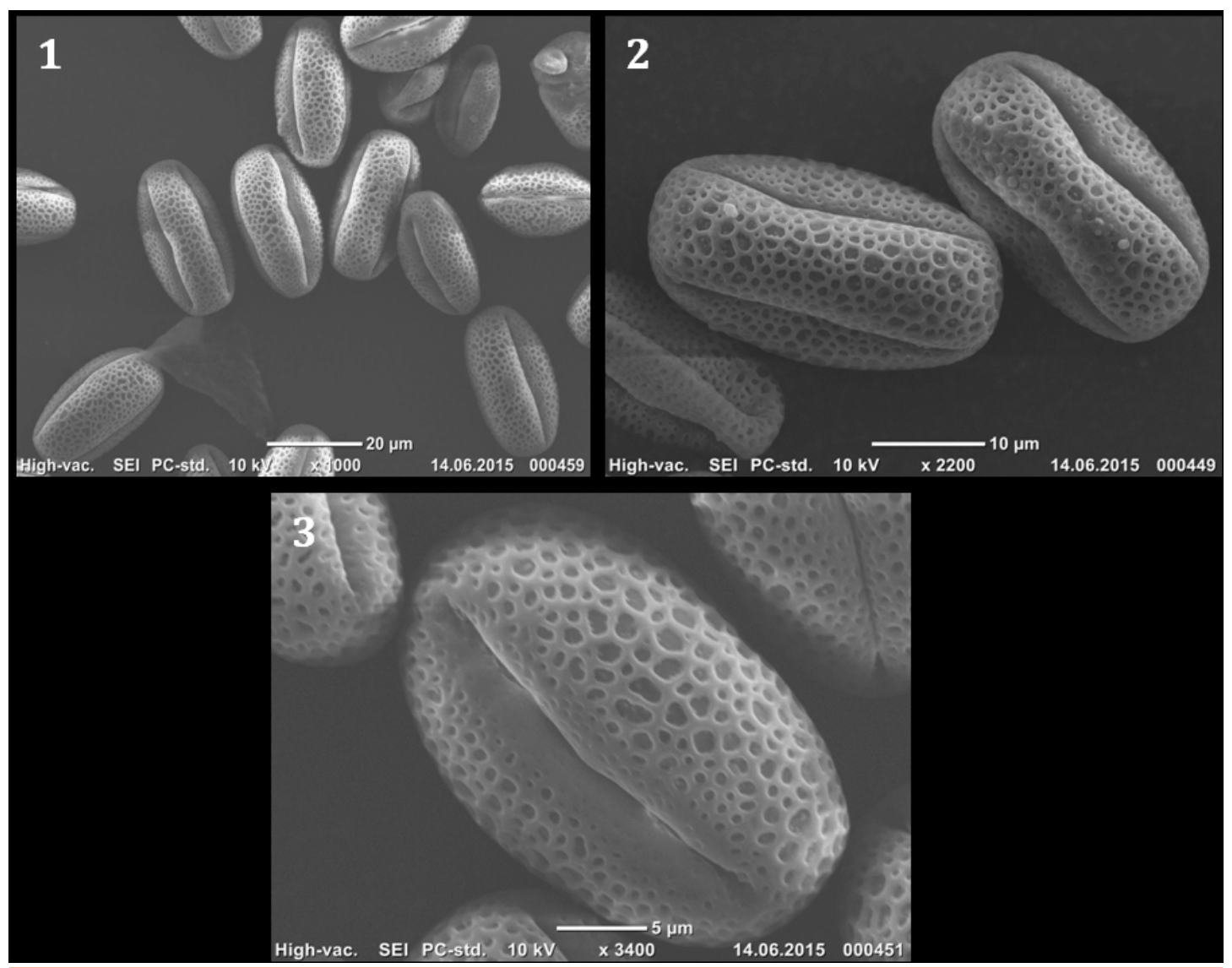

Рисунок 1 Пилкові зерна Lysimachia nummularia L.

1 - загальний вигляд (збільшення × 1000); 2 - загальний вигляд (збільшення × 2 000); 3 - скульптура поверхні (збільшення × 3 400)

Figure 1 Pollen grains of Lysimachia nummularia L.

1 - general view $(\times 1,000) ; 2$ - general view $(\times 2,000) ; 3$ - reticulate exine $(\times 3,400)$ 
Отримані результати дослідження пилкових зерен L. nummularia (Рисунок 1), L. punctata (Рисунок 2) та L. nemorum (Рисунок 3), зібраного на території ППСПМ 'Феофанія', дали можливість підтвердити, що форма пилкового зерна, структура його оболонки детерміновано генетично та несуть специфічні ознаки таксону, до якого належить рослина. Лише за розміром пилкові зерна L. nummularia дещо менші (довжина 30-32 мкм, діаметр 12-13 мкм), ніж у L. punctata (довжина 32-34 мкм, діаметр 17-18 мкм). Загалом, сформований пилок рослин L. nummularia з колекції парку 'Феофанія' на 8,7-11,1 \% має більшу полярну вісь, але менший екваторіальний діаметр, ніж у вище наведеному описі (Kupriyanova and Aleshina, 1978; Kurmanov and Ishbirdin, 2012). Відношення полярного діаметра до екваторіального також більше i становить 1,21-1,14. Тобто, досліджені нами пилкові зерна цього виду мають виражену продовгувато-сфероїдальну форму, порівняно з більш округлим пилком у вказаному описі.
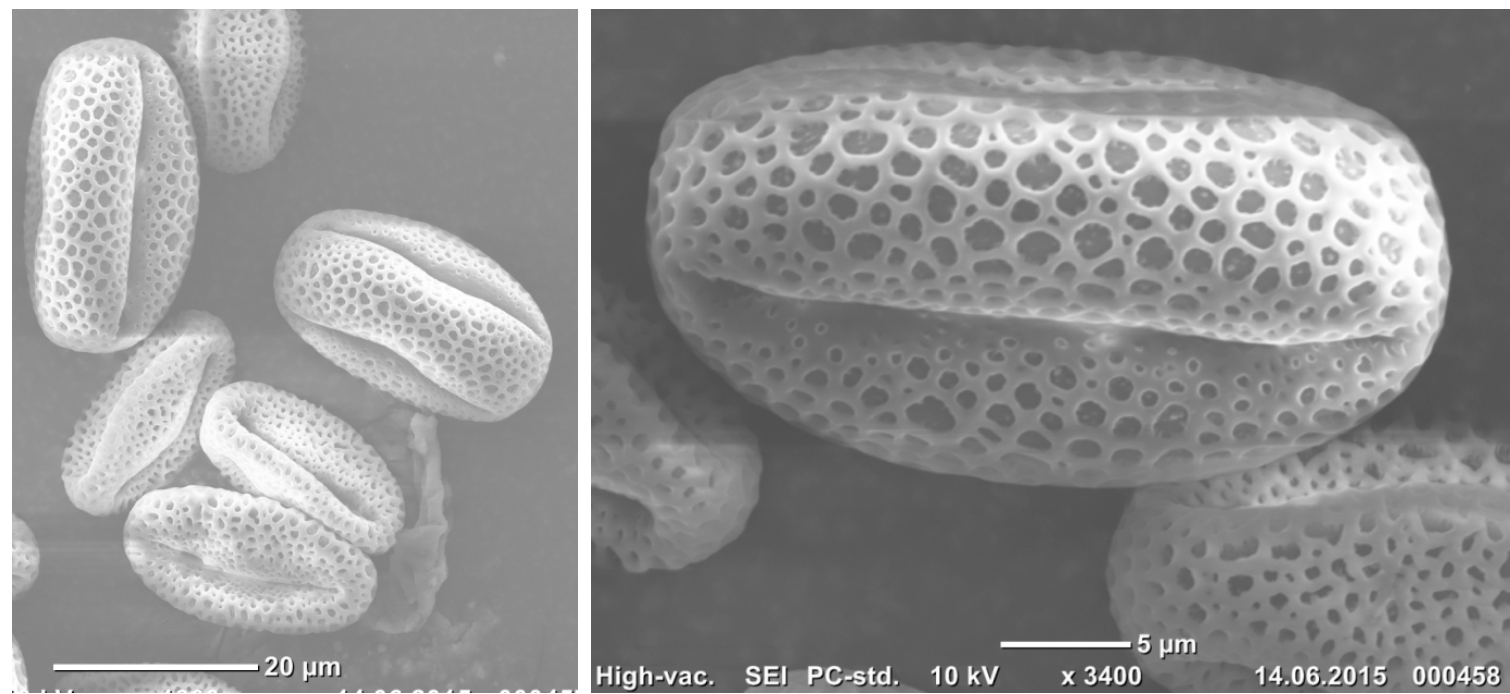

Рисунок 2 Пилкові зерна Lysimachia punctata L.

1 - загальний вигляд (х 1300); 2 - скульптура поверхні (збільшення × 3 400)

Figure 2 Pollen grains of Lysimachia punctata $\mathrm{L}$.

1 - general view $(\times 1,300), 2$ - reticulate exine $(\times 3,400)$

Дослідження стану пилкових зерен L. nummularia, L. punctata та L. vulgaris в процесі розвитку рослин в колекції ППСПМ 'Феофанія', на території озеленення м. Києва i околиць виявило його чутливість до впливу умов вирощування. Для рослин L. nummularia відмічено тенденцію продовження росту пилкових зерен з наступним розвитком квітки. Це спостерігалось у рослин з синантропних ділянок територій 3 незначним антропогенним навантаженням - паркова частина ППСПМ 'Феофанія' i c. Новосілки в околицях Києва (Таблиця 1). Водночас, в популяції цього виду з синантропної ділянки на території парку 'Перемога' м. Києва в період масового квітування рослин не відмічено істотного збільшення діаметру пилкових зерен. 


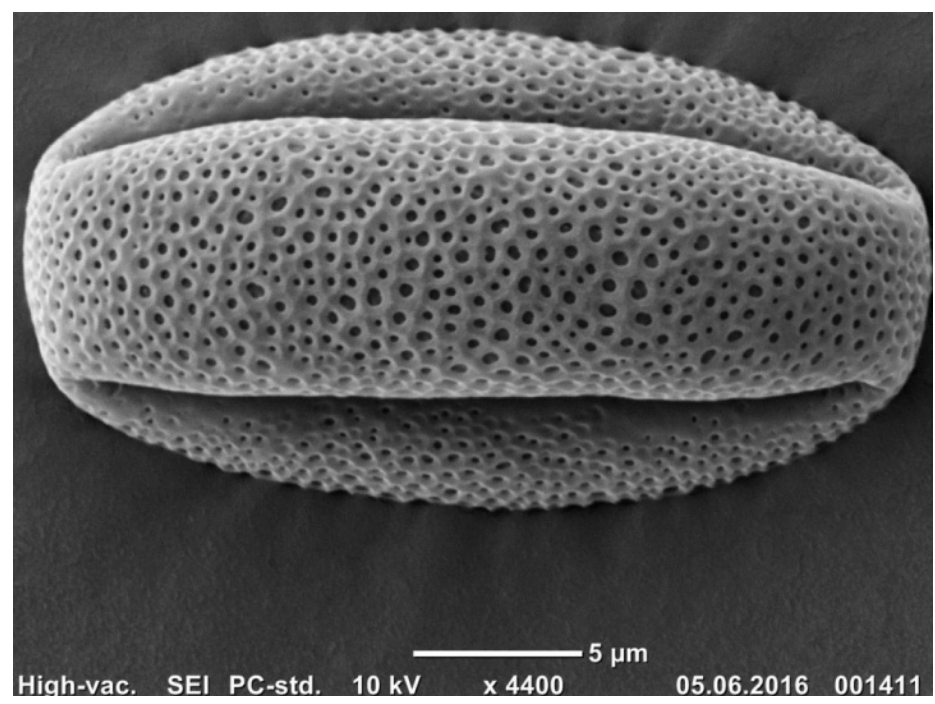

\section{Рисунок 3 Пилкове зерно Lysimachia nemorum L. 1 - загальний вигляд і скульптура поверхні (× 4 400)}

Figure 3 Pollen grain of Lysimachia nemorum L. 1 - general view and reticulate exine $(\times 4,400)$

У рослин L. punctata та L. vulgaris з розкриттям квітки збільшення діаметру пилкових зерен припиняється. При цьому слід врахувати відмінність у розмірах квіток досліджених видів. Якщо середній діаметр квітки L. nummularia - 13-16 мм на різних ділянках ППСПМ 'Феофанія', то діаметр віночка у L. punctata та L. vulgaris досягає 18-20 мм, відповідно (Shpulyar, 2014; Radchenko et al., 2016). Зменшення біометричних показників пилку у фазу цвітіння рослин (на 26,82 \%) відмічено у L. punctata при їх використанні у вуличному озелененні (вул. Заболотного, м. Київ). Слід зазначити, що навіть у фазу бутонізації в рослин з цієї ділянки пилок був дрібніший, ніж у рослин з декоративних насаджень ППСПМ 'Феофанія' (в середньому 21,36 і 22,94 мкм, відповідно).

Тенденцію до зменшення діаметру пилкових зерен після завершення фази бутонізації відмічено і у L. vulgaris, але це зменшення було менш вираженим. При цьому в рослин з лучного угруповання (острів Муромець) та синантропного угруповання (Оболонська набережна, м. Київ) вже в закритому бутоні формувався крупніший пилок, ніж в більш порушених умовах (озеленення центру м. Буча). Найбільш виражене зменшення розмірів пилку з розкриттям квітки було в рослин в умовах з підвищеним впливом антропогенних факторів (Оболонська набережна, м. Київ).

Подібні процеси інгібуючого впливу комплексу екзогенних факторів антропогенного середовища на ріст та життєві показники чоловічого гаметофіту нами встановлювались раніше для інших рослин (Matyashuk and Mazura, 2013; Matyashuk et al., 2014; Matyashuk et al., 2014; Matyashuket al., 2014). 
Таблиця 1 Середній діаметр пилку Lysimachia spp. в різні фази розвитку з різних місцезростань Table 1 The average diameter of pollen of Lysimachia spp. in different phases of development from different locations

\begin{tabular}{|c|c|c|c|c|c|c|}
\hline \multirow[t]{2}{*}{ Моніторингова ділянка } & \multicolumn{3}{|c|}{ Бутон } & \multicolumn{3}{|c|}{ Квітка } \\
\hline & M $\pm \mathbf{m}$ (мкм) & G & V (\%) & M \pm m (мкм) & G & V (\%) \\
\hline \multicolumn{7}{|c|}{ Lysimachia nummularia L. } \\
\hline м. Київ, ПпспМ 'Феофанія' & $22,37 \pm 0,2224$ & 2,47 & 0,0702 & $25,03 \pm 0,3059$ & 4,67 & 0,0864 \\
\hline м. Київ, Парк ‘Перемоги‘ & $26,12 \pm 0,2170$ & 2,35 & 0,0587 & $26,79 \pm 0,1546$ & 1,19 & 0,0408 \\
\hline $\begin{array}{l}\text { с. Новосілки, вул. } \\
\text { Васильківська }\end{array}$ & $22,3 \pm 0,2899$ & 2,01 & 0,0636 & $24,85 \pm 0,1783$ & 1,58 & 0,0507 \\
\hline \multicolumn{7}{|c|}{ Lysimachia punctata L. } \\
\hline м. Київ, ППСПМ 'Феофанія' & $22,94 \pm 0,2350$ & 2,76 & 0,0745 & $22,47 \pm 0,2324$ & 2,70 & 0,0731 \\
\hline м. Київ, вул. Заболотного & $21,36 \pm 0,1670$ & 1,32 & 0,0552 & $15,63 \pm 0,2989$ & 4,68 & 0,1352 \\
\hline \multicolumn{7}{|c|}{ Lysimachia vulgaris L. } \\
\hline м. Київ, Острів Муромець & $25,4 \pm 0,1504$ & 1,13 & 0,0417 & $24,96 \pm 0,2509$ & 3,14 & 0,0710 \\
\hline $\begin{array}{l}\text { м. Київ, Оболонська } \\
\text { Набережна }\end{array}$ & $26,07 \pm 0,2191$ & 2,35 & 0,0588 & $24,6 \pm 0,1855$ & 1,72 & 0,0533 \\
\hline м. Буча Київська обл. & $22,94 \pm 0,1837$ & 1,68 & 0,0566 & $22,86 \pm 0,2050$ & 2,10 & 0,0634 \\
\hline
\end{tabular}

Примітка: M - середнє арифметичне: m - похибка середнього значення; G - дисперсія; V - коефіцієнт варіабельності (\%)

Пилок досліджених видів роду Lysimachia потенційно має високий рівень фертильності. Так, при вирощуванні L. nummularia в сприятливих умовах (паркова частина і лучна ділянка ППСПСМ ‘Феофанія') формується понад 90 \% життєздатного пилку. Хоча при цьому відзначено дуже низьку продуктивність плодоутворення та формування повноцінного насіння у цих рослин. Майже на усіх досліджених ділянках у рослин цього виду відмічалась вища фертильність пилку в закритому дозрілому бутоні, ніж у фазу масового квітування. Так, на ділянках паркової та лучної частини ППСПМ 'Феофанія', а також на синантропній ділянці с. Новосілки (відповідно, ділянки 1, 2, 4) у бутоні формувалось понад 90-92 \% фертильного пилку (Рисунок 4, 5). 3 початком квітування у рослин на ділянках 1 та 2 зменшення середньої фертильності пилку було незначним. У рослин цього виду з лісової ділянки парку 'Феофанія' та з парку “Перемога' (3 та 5 ділянки, відповідно) формувалось від 73 до 75 \% фертильного пилку в бутоні. Але при цьому під час масового цвітіння у рослин з цих місцезростань було відмічено найменшу втрату фертильності пилку. Максимальна втрата (з 92,4 до 57,4 \%) життєвого потенціалу сформованих пилкових зерен з розкриттям квітки спостерігалась у рослин на ділянці 4 (с. Новосілки Київської області).

Так само високий потенціал фертильності пилку відмічений для L. punctata (Рисунок 6). Рослини цього виду з ППСПМ 'Феофанія' вирізнялись значним зростанням фертильності пилку з розвитком квітки. Зростала чутливість сформованого пилку цього виду до умов вирощування при використанні рослин в озелененні населених пунктів - вул. академіка Заболотного, м. Київ та смт. Гребінка Полтавської області 
(ділянки 2, 3, відповідно). Було відмічене зниження фертильності пилку з розкриттям квітки (в середньому до 50-55 \%) на цих ділянках.

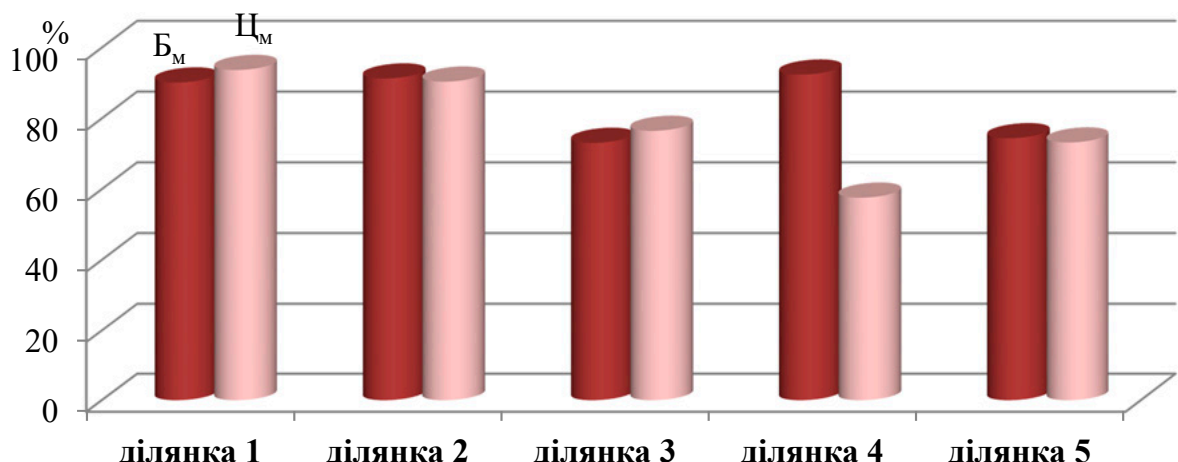

Рисунок 4 Фертильність пилку Lysimachia nummularia L. в фазу бутонізації $\left(\mathrm{Б}_{\mathrm{m}}\right)$ та цвітіння (Ц $)$ в різних умовах вирощування

ділянка 1 - ППСПМ 'Феофанія' (синантропна ділянка, паркова частина); ділянка 2 - ППСПМ 'Феофанія' (напівприродна (порушена) лучна ділянка); ділянка 3 ППСПМ 'Феофанія' (лісове угруповання); ділянка 4 - с. Новосілки Київської області (синантропна ділянка); ділянка 5 - парк 'Перемога' м. Київ (синантропна ділянка)

Figure 4 The fertility of pollen of Lysimachia nummularia L. in budding stage $\left(\mathrm{F}_{\mathrm{M}}\right)$ and flowering period $\left(Ц_{M}\right)$ in different growing conditions

1 - the territory of Feofania Park in Kyiv (sinanthropic area, park part); 2 - the territory of Feofania Park in Kyiv (semi-natural (disturbed) meadow area); 3 - the territory of Feofania Park in Kyiv (forest grouping of plants); 4 - the village of Novosilky, Kyiv region (sinanthropic area); 5 - Peremoga Park in Kyiv (sinanthropic area)

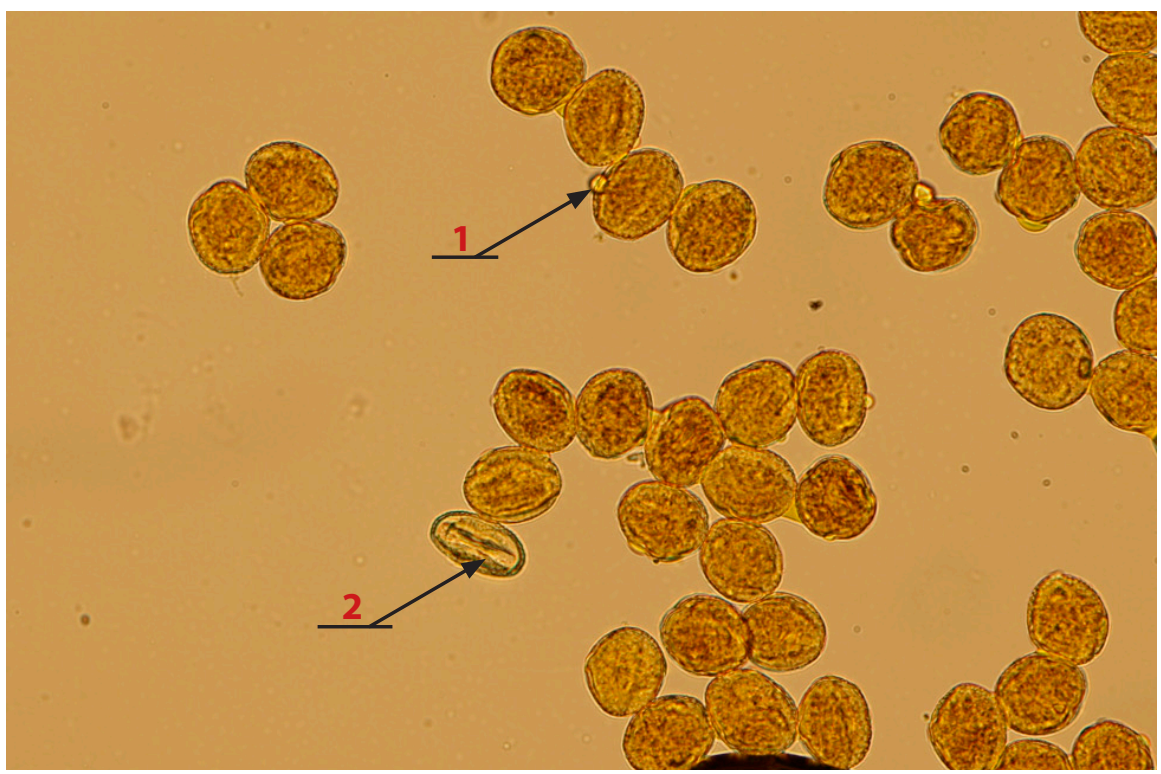

Рисунок 5 Пилкові зерна Lysimachia nummularia L. (ділянка ППСПМ ‘Феофанія’)

1 - фертильні; 2 - стерильні (при збільшенні × 400)

Figure 5 Pollen grains of Lysimachia nummularia L. (from the territory of Feofania Park in Kyiv) 1 - general view of fertile; 2 - sterile pollen $(\times 400)$ 
Досить високу фертильність пилку відмічено у L. vulgaris, особливо при вирощуванні в напівприродних локалітетах та малопорушених умовах (ділянки 1, 2). У фазу бутонізації в рослин на цих ділянках фертильність пилку досягала в середньому 90\% і зберігалась досить високою з подальшим розкриттям квітки (Рисунок 7). Простежувалась чутливість пилку цього виду до умов вирощування у фазу масового цвітіння, коли фертильність на ділянках з підвищеним антропогенним навантаженням (міське озеленення м. Києва і м. Буча Київської області) істотно знижувалась (до 49 \% на ділянці 4).

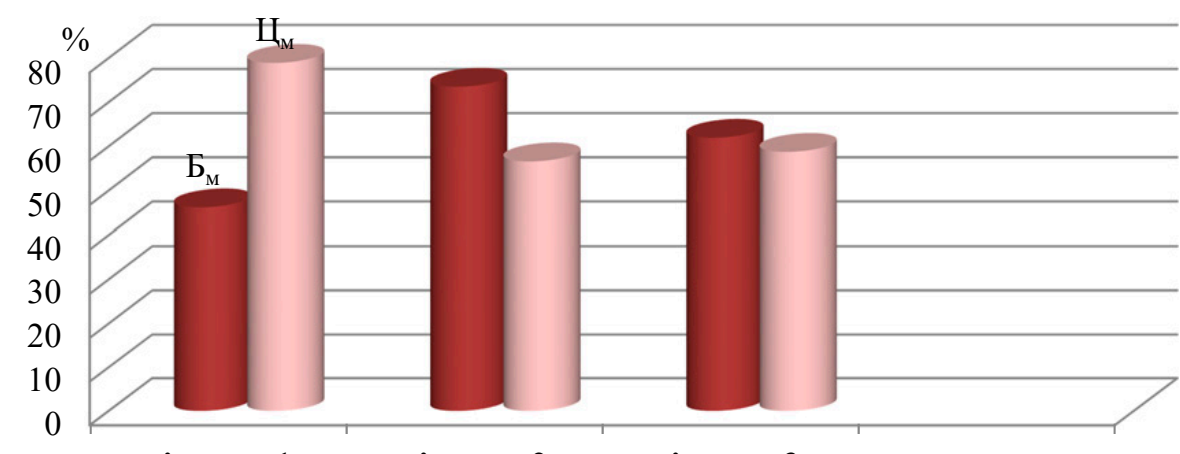

ділянка 1 ділянка 2 ділянка 3

Рисунок 6 Фертильність пилку Lysimachia punctata L. в фазу бутонізації (Б в різних умовах вирощування

ділянка 1 - ППСПм 'Феофанія'; ділянка 2 - вул. академіка Заболотного, м. Київ; ділянка 3 - смт. Гребінка Полтавської області

Figure 6 The fertility of pollen of Lysimachia punctata $\mathrm{L}$. in budding stage $\left(\mathrm{G}_{\mathrm{M}}\right)$ and flowering period $\left(\bigsqcup_{\mathrm{M}}\right)$ in different growing conditions

1 - the territory of Feofania Park in Kyiv; 2 - Zabolotny str., Kyiv; 3 - village Hrebinka, Poltava region

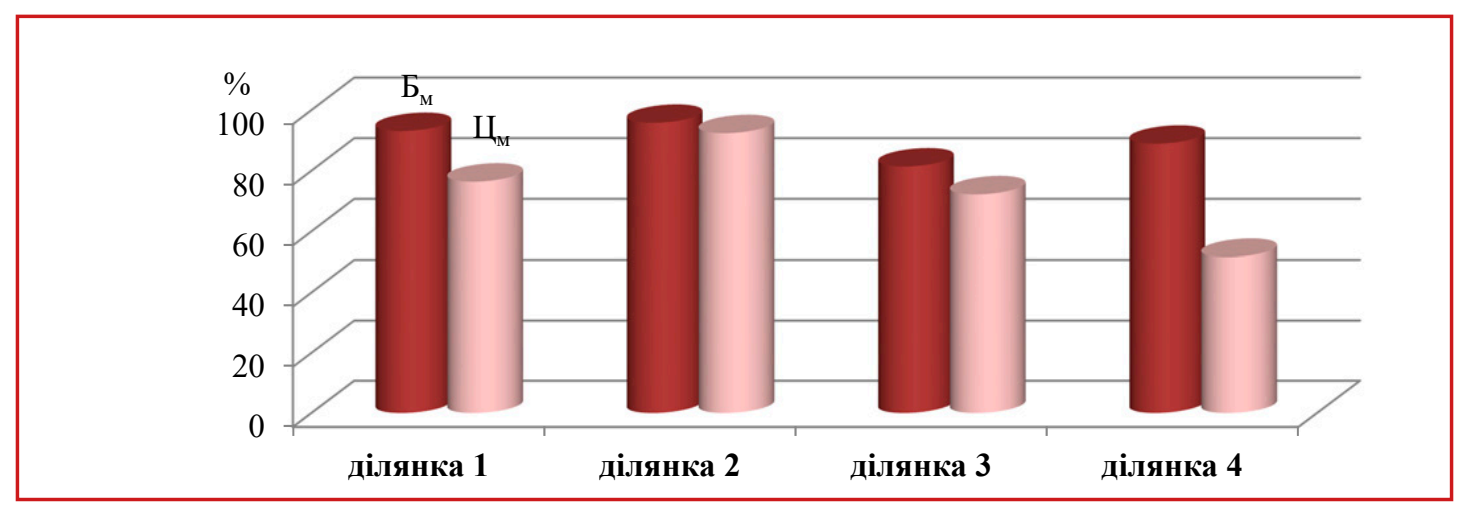

Рисунок 7 Фертильність пилку Lysimachia vulgaris L. в фазу бутонізації (Б умовах вирощування

ділянка 1 - ППСПМ ‘Феофанія'; ділянка 2 - острів Муромець, м. Київ; ділянка 3 - Оболонська набережна, м. Київ; ділянка 4 - м. Буча Київської області

Figure 7 The fertility of pollen of Lysimachia vulgaris L. in budding stage $\left(\mathrm{Б}_{M}\right)$ and flowering period $\left(\bigsqcup_{M}\right)$ in different growing conditions

1 - the territory of Feofania Park in Kyiv; 2 - Muromets island, Kyiv; 3 - Obolon naberezhna, Kyiv; 4 - Bucha (city), Kyiv region 


\section{Висновки}

Дослідження стану пилку видів роду Lysimachia з різних місцезростань м. Києва та його околиць виявило високий життєвий потенціал пилку L. nummularia в різних умовах вирощування та високу стійкість його до впливу зовнішніх факторів. Висока фертильність пилку L. nummularia i L. punctata відмічається при зростанні рослин в більш сприятливих умовах. Встановлено тенденцію до зменшення кількості фертильного пилку з початком цвітіння цих рослин, порівняно з більш життєздатним станом пилку в закритому бутоні. За чутливістю до дії комплексу екзогенних чинників можливо використовувати пилок L. nummularia i L. punctata для індикації якості навколишнього урбанізованого середовища.

\section{Подяка}

Робота виконувалась в межах цільової комплексної міждисциплінарної програми наукових досліджень НАН України 'Молекулярні та клітинні біотехнології для потреб медицини, промисловості та сільського господарства'.

\section{Література}

BESSONOVA, V.P. 1992. Sostoyanie pylcy kak pokazatel zagryazneniya sredy tyazhelymi metallami [State of pollen as an indicator of environmental pollution with heavy metals]. In Ecology. Ekaterinburg. vol. 3. p. 45-50. (In Russian).

BESSONOVA, V.P., BESSONOV, E.P., ZVERKOVSKY, V.M. 2013. Assessment of pollen of wooden plants in the urbothehnogenic ecosystem. In Problems of bioindications and ecology, vol. 18(1), p. 2-17 (In Ukraine).

BESSONOVA, V.P., GRYTZAY, Z.V., LIZHENKO, I.I. 1994. Mozhlyvosti otsinky ekolohichnoi sytuatsii u promyslovomu misti za hametotsydnoiu diieiu na roslyny promyslovykh emisii [Possibilities of estimation of ecological situation in industrial city by gametocidal effect on plants of industrial emissions]. In Ecology and education. Uman, p. 49-51 (In Ukraine).

DIDUKH, Ya.P., KOROTCHENKO, I.A, FITSAILO, T.V., BURDA, R.I., MOYSIYENKO, I.I., PASHKEVYCH, N.A., IAKUSHENKO, D.M., SHEVERA, M.V. 2010. Ekoflora Ukrainy [Ecoflora of Ukraine]. K.: Phytosociocenter, T. 6, 422 p. (In Ukraine).

DZYUBA, O.F. 1999. Palinomorfologiya kak zveno $\mathrm{v}$ tsepi ekologicheskogo monitoringa [Pollenmorphology as a link in the chain of environmental monitoring]. In Ecology. Regulatory, methodological and legal basis of the state of the permanently operating service of oil and gas environmental monitoring and the principles of its financial support. Saint Petersburg: VNIGRI. p. 157-179. (In Russian).

DZYUBA, O.F. 2006. Palinoindikasiya kachestva okruzhayushchey sredy [Pollen-indication of environmental quality]. Saint Petersburg: Nedra. 198 p. (In Russian).

DZYUBA, O.F., BOREYSHA, I.K., YAKOVLEVA, T.L. 2001. Kachestvo pyl'tsy vysshikh rasteniy i nekotorykh kletochnykh struktur zhivotnykh organizmov v usloviyakh promyshlennoy ploshchadki LAES i goroda Sosnovyy Bor [The quality of the pollen of higher plants and some cellular structures of living organisms in a industrial area of the city of Leningrad NPP and Sosnovyy Bor town]. In Pollen as an indicator of the state of the environment and palinoecological reconstructions: International Workshop. Saint Petersburg: VNIGRI. p. 69-78. (In Russian).

DZYUBA, O.F., KOCHUBEY, O.V. 2014. Kachestvo pyl'tsy rasteniy kak indikator intensivnosti vozdeystviya neftegazovogo kompleksa na prirodnuyu sredu ohranyaemyh territoriy Rossii (Quality of pollen grains of plants as the indication of intensity of impact of the oil and gas complex on environment 
of the protected territories of Russia). In Neftegazovaya geologiya. Teoriya i praktika, T.9(4), (In Russian)

FRENKEL, R., GADUN, E. 1982. Mehanizmy opyleniya, razmnozheniya i selekcii rasteniy [Mechanisms of pollination, reproduction and plant breeding]. Moskva : Kolos. 384 p. (In Russian).

GLAZUNOVA, K.P. 2001. Pyl'tsa kak indikator negativnykh faktorov okruzhayushchey sredy: embriologicheskiy aspekt [Pollen as an indicator of negative environmental factors: embryological aspect]. In Pollen as an indicator of the state of the environment and palinoecological reconstructions: International Workshop. Saint Petersburg: VNIGRI. p. 61-63. (In Russian).

GOLUBINSKIY, I.N. 1974. Biologiya prorastaniya pylcy [Biology of pollen germination]. Kiev : Nauk. Dumka. 368 p. (In Russian).

GOROVAYA, A.I., SKVORCOVA, T.V., KLIMKINA, I.I., PAVLYUCHENKO, A.V. 2003. Citogeneticheskoe testirovanie kachestva sredy [Cytogenetic testing of environmental quality]. In Anthropogenicchanged environment of Ukraine: risks to public health and ecological systems. Kiev : Chornobilinterinform, p. 502-517.

GRYTZAY, Z.V., TRYPHONOV, M.O. 2015. Influence of emissions of Prydniprovs'k combined heat and power station of Dnipropetrovsk city on Tilia genus blooming indicators. In Issues of steppe forest science and foresting recultivation of lands. vol. 44, p. 91-95 (In Ukraine). Available at: http://nbuv. gov.ua/UJRN/pslis_2015_44_18

KAVELENOVA, L.M. 2003. Problemy organizacii sistemy fitomonitoringa gorodskoy sredy $v$ usloviyah lesostepi [Problems of organization of the system of phytomonitoring of the urban environment in the conditions of Forest-Steppe]. Samara: Samarskiy un-t. 124 p. (In Russian).

KUPRIYANOVA, L.A. ALESHINA, L.A. 1978. Pylca dvudolnyh rasteniy flory evropeyskoy chasti SSSR. Lamiaceae-Zygophyllaceae [Pollen of dicotyledonous plants in the flora of the European part of the USSR. Lamiaceae-Zygophyllaceae]. Leningrad : Nauka, vol. 1, 170 p. [In Russian].

KUPRIYANOVA, L.A., ALESHINA, L.A. 1972. Pylca i spory rasteniy flory evropeyskoy chasti SSSR. Rukovodstvo $v$ treh tomah [Pollen and spores of plants in the flora of the European part of the USSR]. Leningrad : Nauka, 1972. T. 2. p. 184 [In Russian].

KURMANOV, R.G., ISHBIRDIN, A.R. 2012. Palinologiya: uchebnoe posobie (Palinology: a tutorial). Ufa: RIC BashGU. 92 p.

LOC, P.K., Hu, C.M. 2011. Lysimachia vietnamensis and L. verbascifolia spp. nov. (Primulaceae) from Vietnam. In Nordic J Bot;; no. 29, p. 601-604. https://doi.org/10.1111/j.1756-1051.2011.01174.x

MATYASHUK, R.K., KONYAKIN, S.M., PROKOPUK, Yu.S., TKACHENKO, I.V. 2014. Otsinka stanu pylku Robinia viscosa Vent. v urboekosystemakh Ukrainy [The evaluation of Robinia viscosa Vent. pollen in the urban ecosystems of Ukraine]. In Scientific Issues Ternopil Volodymyr Hnatiuk National Pedagogical University Series: Biology. Vol. 59(2). p. 14-18. (In Ukraine). Available at: https:// scholar.google.com.ua/citations?user=JuBdk-oAAAAJ\&hl=ru\&authuser=1

MATYASHUK, R.K., KONYAKIN, S.M., TKACHENKO, I.V., PROKOPUK, Yu.S. 2014. Chuvstvitelnost reproduktivnoy sfery Tilia cordata L. k usloviyam proizrastaniya [Sensitivity of the reproductive sphere of Tilia cordata L. to the conditions of growth]. In Biodiversity and sustainability of living systems. Belgorod, p. 44-45. ISBN 978-5-9571-1002-6. (In Russian).

MATYASHUK, R.K., MAZURA, M.Yu. 2013. Chutlyvist okremykh sortiv kanny do vplyvu abiotychnykh chynnykiv (Sensitivity of individual genomes Cannes to the influence of abiotic factors). In Scientific reports NULES of Ukraine. Available at: http://nbuv.gov.ua/j-pdf/Nd_2013_6_2.pdf (In Ukraine).

MATYASHUK, R.K., MAZURA, M.Yu., TKACHENKO, I.V.2014. Stan pylku kanny v umovakh urbanizovanykh terytorii (Canna pollen quality in the urban areas). In The Bulletin of Kharkiv national agrarian university, vol. 3(33), p. 43-51. (In Ukraine). Available at: https://knau.kharkov.ua/vsnik-hnau2014-vip-3-33.html

ORDER of the Ministry of Health of Ukraine No. 116 dated 13.03.2007 On approval of methodological recommendations Examination and territorial distribution by the degree of the impact 
of anthropogenic factors on the condition of environmental objects using cytogenetic methods". In Official Bulletin of Ukraine, vol. 4, p. 186-209. (In Ukraine).

PAUSHEVA, Z.P. 1988. Praktikum po citologii rasteniy (Workshop on plant cytology). $4^{\text {th }}$ ed., Revised and additional. Moskva : Agropromizdat. 271 p. (In Russian).

PETROVICH, I.V. 1976. Muzhskoy gametofit amarillisovyh, bobovyh i zlakovyh rasteniy [Male gametophyte of amaryllises, legumes and cereals plants]. Kishinev : Shtiinca. 120 p. (In Russian).

POGOSYAN, V.S., SIMONYAN, E.G., DZHIGARDZHYAN, E.M., ARUTYUNYAN, R.M. 1991. Ocenka genotoksicheskogo deystviya antropogennyh faktorov na rasteniya $\mathrm{v}$ gorodskih usloviyah [Evaluation of the genotoxic effect of anthropogenic factors on plants in urban environments]. In Cytology and genetics, vol. 25(1), p. 23-30. (In Russian).

PUNT, W., BLACKMORE, S., NILSSON, S., Le THOMAS, A. 1994. Glossary of pollen and spore terminology. Utrecht: LPP Foundation, $71 \mathrm{p}$.

RADCHENKO, V.G., MATIASHUK, R.K., TKACHENKO, I.V., PROKOPUK, Yu.S. 2016. Perspektyvy praktychnoho vykorystannia predstavnykiv rodu Lysimachia [Prospects of the practical use of representatives of the genus Lysimachia]. In Agrobiodiversity for improving nutrition, health, and life quality. p. 377-382. (In Ukraine). Available at: https://ves.uniag.sk/files/ pdf/8pnibsjxdh1s8mg69m8x8w3d7vd2ed.pdf

SHAO, J., ZHANG, X. 2005. Pollen morphology of Lysimachia and its systematic implication. In Acta Micropalaeontologica Sin., vol. 22(1). p. 78-86.

SHPULYAR, S.B. 2014. Likarski roslyny Ivano-Frankivshchyny [Medicinal plants of Ivano-Frankivsk region]. Ivano-Frankivsk. 112 p. (In Ukraine).

TOKAREV, P.I. 2002. Morfologiya i ultrastruktura pylcevyh zeren [Morphology and ultrastructure of the pollen grains]. Pod red. N.R. Meyern-Melikyan Moskva. M.: Publisher nauch. ed. KVM, 51 p. (In Russian).

TSYMBALYUK, Z.M., MOSYAKIN, S.L. 2013. Atlas pylkovykh zeren predstavnykiv rodyn Plantaginaceae $i$ Scrophulariaceae [Atlas of pollen grains of representatives of families Plantaginaceae and Scrophulariaceae]. Kiev : Nash format. 276 p. (In Ukraine).

WANG, Z.-H., LI, X.-W., LIU, E.-D., SHANGGUAN, F.-Zh., CHANG, X.-k. 2016. Lysimachia septemfida (Primulaceae), a new species from Yunnan, China. In Plant Diversity, vol. 38(4), p. 201-206. https:// doi.org/10.1016/j.pld.2016.08.002

ZHANG, C.Y., Wang, F.Y., Yan, H.F., Hao, G., Hu, C.M., Ge, X.J. 2012. Testing DNA barcoding in closely related groups of Lysimachia L. (Myrsinaceae). In Mol Ecol. Resour; vol. 12(1), p. 98-108. https://doi. org/10.1111/j.1755-0998.2011. 03076.X

ZHOU, J.-J., YU, X.-L., DENG, Y.-F., YAN, H.-F., LIN, Z.-L. 2015. Lysimachia huangsangensis (Primulaceae), a New Species from Hunan, China. In PLoS ONE, vol. 10(7), p. e0132713. https://doi.org/10.1371/ journal.pone.0132713 